\title{
The Lycian League and Olympus in Eastern Lycia
}

\author{
Doğu Likya'da Likya Birliği ve Olympus
}

\section{Elif ÖZER*}

\begin{abstract}
This paper aims to analyse the relationship between the Lycian League and Olympus in Eastern Lycia. One of the six cities with three votes in the Lycian League, Olympus was no longer a member of the League after the pirate chief Zenicetes captured the city. Olympus issued Lycian League coins until it left the League, when it began to mint coins termed today Pseudo-League coins. These coins seem to have been struck from the end the II century B.C. and continued to be minted until 77 B.C. Although they imitated League examples, they do not carry the name of the federation. Olympus was probably struck from the League because of its capture by Zenicetes or because of its collaboration with the pirates. Olympus coined as a member of the League in the II century B.C. but it could not be determined exactly when the city became a member of the Lycian League. Olympus and Phaselis minted Lycian League type coins in Period II, Series 1 with issues dating from 167 to 130 B.C. At the end of the 1970's a hoard containing 133 League coins was discovered, probably in Kemer. Of these coins 91, are from Eastern Lycia, with 76 from Olympus and Phaselis and 15 from Limyra, Rhodiapolis and Gagai. There are also 58 Olympus League coins.
\end{abstract}

Anahtar sözcükler: Lycia, Lycian League, Olympus, Coin, Pseudo-League Coin, Piracy

Özet: Bu makalede Doğu Lykia'daki Olympos antik kenti ile Lykia Birliği arasındaki ilişkiyi incelenmeye çalışılacaktır. Lykia Birliği'nde 3 oy hakkına sahip Olympos'un, Zeniketes'in kenti zapt etmesinin ardından Birlik ile ilişkisi kesilmiştir. Lykia Birliği’nden ayrılıncaya kadar Birlik sikkeleri basan Olympos daha sonra Pseudo Birlik Sikkeleri adı verilen sikkeler basmaya başlamıştır. Pseudo Birlik Sikkeleri M.Ö. II. yüzyıl sonlarında basılmaya başlamış ve M.Ö. 77 yılına kadar devam etmiş gibi görünür. Bu sikkeler Birlik sikkelerini taklit etmelerine rağmen federasyonun adını taşımamışlardır. Olympos'un Birlik'ten ayrılma nedeni olasılıkla Zeniketes tarafından zapt edilmesi veya korsanlar ile işbirliğine girmesidir. Olympos M.Ö. II. yüzyılda Birliğin üyesi olarak sikke basmıştır bununla birlikte Lykia Birliği'ne ne zaman üye olduğunu saptanamamaktadır. Olympos ve Phaselis M.Ö. 167-130 yılları arasında Lykia Birliği tipinde Periyot II, Seri 1 ve Periyot II Seri 1 sikkeleri basmıştır. 1970'lerin sonunla olasılıkla Kemer'de 133 adet Birlik sikkesini kapsayan bir hazine keşfedilmiştir. Bu sikkelerden 91 tanesi Doğu Lykia'dandır. 76 tanesi Olympos ve Phaselis'ten, 15 tanesi ise Limyra, Rhodiapolis ve Gagai'dendir. Ayrica 58 tane Olympos'a ait Birlik sikkesi ele geçmiştir.

Keywords: Lykia, Lykia Birliği, Olympos, Sikke, Pseudo Birlik Sikkeleri, Korsanlık

Artemidoros who mentioned the League was the first to do so amongst ancient writers; however this information comes from Strabo who quoted from Artemidoros (Strabo, XIV. 3. 3). The existence of the League during the Hellenistic period is known from ancient sources and Lycian

\footnotetext{
* Doç. Dr., Pamukkale Üniversitesi, Fen-Edebiyat Fakültesi, Arkeoloji Bölümü, Kampüs, Denizli, eozer@pau.edu.tr Olympos Araştırma Başkanı Prof. Dr. E. Parman'a, Olympos Kazı Başkanı B. Y. Olcay Uçkan’a ve tüm kazı ekibine, Olympos'ta çalışmama izin verdikleri için teşekkürlerimi sunarım.
} 
League coins were struck in the II century B.C. (Larsen, 1968, 248; Treuber, 1887, 180; Troxell, $1982,1)$. Some scholars have dated the League's foundation earlier than 167 B.C., although it seems that it existed in 167 B.C. (Treuber, 1887, 163-166; Meyer, 1925, 147; Houwink Ten Cate, 1961, 16; Borchhardt, 1999, 126). According to these scholars, the League was formed at the end of the III. or the beginning of the II century B.C. (Treuber, 1887, 149; Troxell, 1982, 1011; Behrwald, 2000, 165) The Lycians are recorded in the Athenian Tribute List, the most important evidence for the Classical existence of the League. The Lycians had given 10 talents to the Athenian League recorded as a statement "The Lycians" in 452/451 B.C. and "The Lycians and confident partisan" in 451/450 B.C. in the Athenian Tribute List (Wade-Mcgregor, 1968, 81, 334-335; Houwink Ten Cate 1961, 5; Childs 1981, 56; Troxell 1982, 6-10). They left the Athenian League around the 440's B.C. In particular the statement "The Lycians and confident partisans" in 446/4 B.C. is understood as indicating the existance of the League in the Athenian Tribute List (Jones, 1998, 97-98). It is believed that was impossible to pay an annual payment of " 10 talents" without a regular financial organization and associated treasury for this annual payment as is mentioned in the list (Keen 1998, 51).

Many scholars have examined the expression Lykioi kai synteleis (Morkholm-Zahle, 1972, 82; Jameson, 1980, 832; Bryce, 1986, 105; Zimmermann, 1992a, 22; Keen, 1998, 51; Jones, $1998,97)$. Jones $(1998,97)$ considered that the ethnic place of origin was not Lycia alluded to in terms of synteleis. Childs (1981, 57-59) made two assumptions concerning the term synteleis. Firstly, he conjectured that the division between the Lycians and syteleis he described as a legal division between the inhabitants of the city and periokoi. Secondly, he suggested that this related to the aims of the government of Athens. However Bryce did not agree with the first hypothesis of Childs. Bryce (1986, 105-106) emphasized that such a kind of internal division was not of interest to Athens. He defined synteleis as describing the political state of the cities and regions. On the other hand, the suggestion of Child's is not much more acceptable because there is also evidence which did not mention this kind of internal division in the Aramaic version of the Trilingual inscription from the Letoon (Keen, 1998, 41).

The Dynasts who ruled under the Achamenid sovereignty minted coins which carry their own names. The coins from this period, termed the "Dynastic Period (520/10-360 B.C.)", are divided into four groups. It is thought that about thirty dynasts and at least thirteen cities struck coins during this period (Borchhardt, 1999, 125). The issues of the Lycian Dynastic period probably ended through the revolt of the Lycians in the Dynasts rebellion, except for Phaselis, which was a Greek colony around the 360's B.C. (Borchhardt, 1999, 127). Dynastic coins mostly carry the emblem of the triskeles indicating a shared unity, and it is suggested that the triskeles indicated the characteristic of a confederation within this region (Troxell, 1982, 10; Bean-Mitchell, 1996, 895). Larsen $(1945,73-74 ; 1968,241)$ states the existence of the League was not yet certainly proved in the Classical period and in the IV century B.C. it was of Anatolian, not Greek origin. According to Larsen, aspects of the League before the Hellenistic period, derived from forms developed in the Achamenid period. However, there is no complete agreement as to if this can be described as a true confederation or a federal state (Bryce, 1986, 102). Supported by both tomb epitaphs and the coins minted by these dynasties, it is argued that the region was ruled by local dynasties under Achamenid hegemony.

Consequently, it is suggested that the Classical Lycian League could be understood as being "The Federation of Lycian Rulers" (Childs, 1981, 58; Bean, 1997a, 28; Jones, 1998, 97). It was observed that the trisceles or triscelion was often struck on the earlier coins and it was understood as being the symbol of the legal organization and of this Lycian confederation (Head, 
1967, 688; Morkholm-Zahle, 1972, 82; Jones, 1998, 97).

The reorganization of the League in the III century B.C. is asserted from a few epigraphic and from some written sources. Pausanias described Tlepolemus a winner at the Olympiad of 254 B.C. as a Lycian [Tlepolemus, son of Artapates, of Xanthus in Lycia was eminent official of the same king and of his successor, Ptolemy III Euergetes, see: Habicht, 1998, 8; Pausanias (V. 8. 11) says that Tlepolemus of Lycia won an Olympic victory in 254 B.C. in the race of the colts, one of the prestigious hippic events] which is offered as a proof of the existence of the League in this period. Because the Lycian League is understood as already in being during the era of Pausanias it is possible to relate this to the League. The suggestion of Larsen was not accepted by Zimmerman and Keen. They note figures denoted as Greeks are identified as

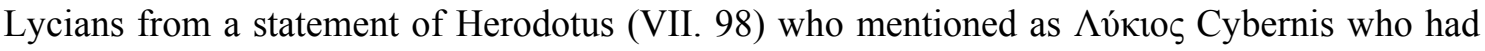
been a commander in Xerxes' navy. However, Herodotus statement clarifies another subject as Herodotus who wrote his book in the V century B.C., recording $\Lambda$ v́кı same as the statement made by Pausanias concerning Tlepolemus. Pausanias (V. 8.11) can probably be mentioned as employing this kind of expression according to the conditions of his era, when he cited a man who had lived long before his period. Herodotus also could have chosen this particular statement like Pausanias because of the conditions of his era, which means it also serves as another indication of the Lycian League during this period.

Although it is generally offered as a proof of citizenship in federal Lycia, the use of $\Lambda$ v́кı $\dot{\alpha} \pi$ ò $\kappa \tau \lambda$ and variations in the Hellenistic age (Troxell, 1982, 13), it can only be mentioned as federalism if it is provided with a city and term (Zimmermann, 1992b, 211). One of the arguments is an inscription found in Miletus, dated to 212/211 B.C. (Moretti, 1962, 188-190; Günther, 1988, 412). On another inscription found in Xanthus and dated to 206/5 B.C. a relationship between the Cytenians and Lycia is mentioned (Patterson, 2010, 118-119). Formerly, this was offered as evidence about the Lycian League in the Hellenistic period but subsequently it has been accepted that this ligament implied a syngeneia (a closeness) between the Xanthians and the Cytenians (Keen, 1998, 178).

One of the most important arguments for the Lycian League is an honorary inscription dedicated to archisomatophylax Ptolemy by the League in Alexandria. It employs the statement

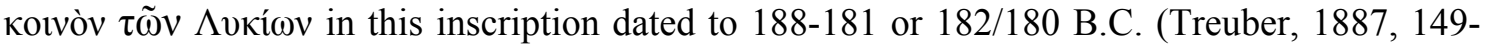
59; Larsen, 1945, 72; Von Aulock, 1977, 16; Troxell 1982, 11; Behrwald, 2000, 69). It is not

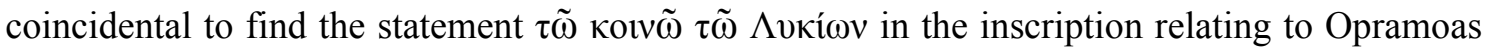
from Rhodiapolis (TAM II 905, XI, B = [40] 11. 12-13; Kokkinia 2000, 193-196; Kokkinia 2012, 327-339). Another important inscription, dedicated to Orthagoras found in Araxa (Moretti, 1950, 325-348) which records Araxa fought Bubon and Cibyra after Orthagoras had sent a prophet to complaint to the Lycian League (Magie, 1950, 1122, dn. 30; Moretti, 1950, 327-348; Larsen, 1956, 151-167; Troxel, 1982, 11). It is known that Lysanias and Eudemus who were supported by Rhodes ruled as a tyrant at the beginning of the II century B.C. but this ended after a short time due to its prevention by the Lycian League. This also could be understood as providing evidence of the League being a federal state, at least at the beginning of the II century B.C. (Bean, 1948, 53; Keen, 1998, 177). After analyzing the arguments which have been suggested for the institution of the League, the probable date of its foundation was at the end of the III century B.C.

Lycia was ruled by the Ptolemy I Soter in 295 B.C. and then by Antiochus III in 197 B.C. (Houwink ten Cate, 1961, 15; Troxell, 1982, 6-7; Jones, 1998, 101). It is not entirely clear if the dominant families in the Classical period continued with their power or not, but from docu- 
mentation there was political change and Lycian cities became Greek poleis during this period (Keen, 1998, 186-187).

The influence of Greek began in the IV century B.C. and reached its peak in the Ptolemaic period when Hellenization reached its greatest extent. It seems the influence of Greek on the Lycian League appeared from the Ptolemaic period or Antiochus III who conquered in 197 B.C. From the arguments which are offered for the Lycian League it has been deduced from these consequences that Lycia previously had been ruled as a federal state.

The organization of the League certainly underwent some new arrangements. It is not understood to what degree the League served to protect and to maintain a Lycian identity. Indeed although not directly related to the Lycian League, when one looks at Lycian tombs, one finds the Lycian gothic lid shape did not lose its prominent form during the Roman Period and when one finds Lycian names such as Opramoas, one has the impression that the League still supported elements of the past into the Roman Period.

The Lycian League influenced by the internal war however protected its independence allied with Rome in the second part of the I century B.C. (App. civ. IV. 60). Pompeius and Caesar demanded both soldiers and vessels from the Lycians. Brutus, who obtained both troops and money against the triumviri is besieged to Xanthus and claimed 150 talents from the Lycian League in 42 B.C. (App. civ. IV. 10. 76-80; see also, Behrwald, 2000, 151). It is indicated from an inscription which has not yet been published, that Iulius Caesar had relations with the Lycian League before Brutus. Iulius Caesar exempted from tax the Lycians after the behavior of Brutus who complained to the Lycian League. But it can also be understood that the League was not giving its decisions independently it was but depended on Rome. The complexities and disagreements continued in the Lycia League, although Lycia had greater privileges when compared to the other regions in Anatolia during the reign of Augustus.

The League did not prevent the kind of conflict that seems to have arisen from the politically jealousies between the powerful families in Lycia (Adak, 2002, 134). These negative conditions of region are termed anarchy in the inscription of the Stadiasmus Patarensis (ŞahinAdak, 2007). The Senate of Rome declared Lycia a Roman province by the special order of Emperor Claudius (Suet. Claud. 25; 25; Dio Cass. LX. 17. 3-4). Lycia was joined with Pamphylia by Claudius then very important constitutional changes were been in the basic law of the League (Wörlle, 1998, 96, 123). However some researchers have not agreed with this and have contested this idea. They claimed that the certain information relates rather to the period of Vespasianus (Brandt, 1992, 98-99; Şahin, 1994, 130-131).

The League is hardly controlled and all the estimates of it must be offered to the governor of the province that was appointed by Rome. Under Nero, Lycia regained its independece but was then again merged with Pamphylia as a province by Vespasianus in 74 A.D. (Bean, 1997a, 30; Jones, 1998,106 , no. 15, 134, no. 21). However this hypothesis has been disputed since 2000 by İplikçioğlu, Adak and Wilson (İplikçioğlu, 2008, 5-23; Adak, \& Wilson, 2012, 1-40). It is known from inscriptions of III. c. A.D., that despite changes within the League during the reign of Claudius (Milner, 1991, 42-46) it remained an entity. The decisions of League also has not offer to the governor of region, however in its internal affairs there were many privileges. The courts of the League continued to function and the tax which was given to the Rome was collected by the officers of the League (Bean, 1997a, 28-29; Jones, 1998, 106, no. 16; Takmer, 2007, 165-188). The contributions and depth differed in respect to the votes of the member cities of the League. The devotion of the League to Rome can be understood from the temples raised to the Imperial cult and the priests who were placed in charge of these temples (TAM II 
177; 275, 557, 943, 1188; Borchhardt, 1999, 20; Büyükkolanc1, 2004, 209-211; Price, 2004, 115).

According to Livy, Patara was the center (caput gentis) of the League (Per. XXXVII. 15. 6) and the Temple of Apollon at Patara was possibly the place which housed the archives of the League (Larsen, 1968, 256; Troxell, 1982, 52; Borchhardt, 1999, 16; Bean, 1997a, 88; Behrwald, 2000, 181). The president of the League termed lyciarch was elected by those people with a voice in the League, through the boule (city council) and eclesia (nation assembly). The lyciarch (Reitzenstein, 2011, 476) officiated as a chief priest of the goddess of Rome cult and was strategos (supreme commander) of the state army. In command of land forces was the hipparchus the League rider. The management board of the League was administered by a secretary termed grammateus and was assisted by hypogrammateus. The person in charge of the federal court was known as epistates, and the clerk of the treasury termed tameias. A man is termed archiphylax (Hall-Milner, 1994, 33-42; TAM II 256; 265; 319; 495), and his assistant the hypophylax (More information see: Zimmermann, 1992a, 235; 1993, 116-119, no. 1-22; Borchhardt, 1999, 15-16; Tietz, 2003, 146) were responsible both for the security affairs of the League and for the collection of taxes (Kokkinia, 2000, 119; Gygax, 2001, 20; Öztürk, 2007, 166).

It is interesting that women obtained a high level status as officers of the League during the Roman period and that they played major roles in the League and in many of the inscriptions found in Arneia and Sidyma, women are mentioned as gymnasiarchi and lyciarchi (TAM II 189, 190, 277, 766; Behrwald, 2000, 211; for more information see: Reitzenstein, 2011). In our opinion the matriarchal system mentioned by Herodotus and Valerius Maximus maybe the reason for this prominence of women reflected (Hdt. II. 173; Val. Max. II. 16. 3) into Roman times, but this remains unproven.

We learn of the relationship between Olympus and the Lycian League from Strabo:

"There are twenty-three cities that share in the vote. They come together from each city to a general congress, after choosing whatever city they approve of. The largest of the cities control three votes each, the medium-sized two, and the rest one. In the same proportion, also, they make contributions and discharge other liturgies. Artemidorus said that the six largest were Xanthus, Patara, Pinara, Olympus, Myra and Tlos the last named being situated near the pass that leads over into Cibyra. At the congress they first choose a "Lyciarch," and then other officials of the League; and general courts of justice are designated. In earlier times they would deliberate about war and peace and alliances, but now they naturally do not do so, since these matters necessarily lie in the power of the Romans, except, perhaps, when the Romans should give them permission or it should be for their benefit. Likewise, judges and magistrates are elected from the several cities in the same proportion. And since they lived under such a good government, they remained ever free under the Romans" (Strab. XIV. 3. 3).

Olympus had a very important status being one of only six cities with three votes in the League (Strab. XIV. 3. 3). It is thought that the voting rights had been determined according to distribution of population in the earlier stages of the League (Larsen, 1945, 81-87). Four of the six cities with three votes were in the Xanthus Valley, but Myra was in Central Lycia and Olympus was in Eastern Lycia. It is accepted that Olympus represented the eastern part of the region in the Lycian League (Bean 1997b, 149). 
Although one cannot prove the existance of Olympus prior to its membership in the League; a wall at Olympus dating from the end of the IV century B.C. is taken as evidence for its prior existance (Troxell, 1982, 69; Bean, 1997b, 154) and so Olympus was founded at the latest during the Hellenistic period (There are two pieces of evidence in the city indicating a settlement dating at the latest from the Hellenistic period. One is a polygonal wall discovered in the city, dating from the Hellenistic period from the technique employed, common in the Lycia region during the Hellenistic age. The other is an inscription carved on a sarcophagus on the acropolis. We are again indebted to B. İplikçioğlu who informed us that there is a Hellenistic inscription on this sarcophagus (Oly01/316). Until recently it was the written evidence and the minting of Lycian League coins which provided the perhaps somewhat late date for the foundation of the city. A settlement on Mount Musa provided a further new argument for the antiquity of the foundation of this city (Adak, 2004, 27) when linked to Cicero's statement that: "It was old city" (Cic. Verr. II. 1. 56). The rock-cut tombs in the Asartas settlement are dated to the IV century B.C. (Işın, 1994, 68. Abb.1-3; Wörlle, 1997, 24, Abb.1-2; Borchhardt, 1997, 814, Abb. 11-16), in the territory of Olympus, which could also be another indication supporting an earlier date for the foundation of the city.

Olympus which coined in the name of the Lycian League was therefore a member of the League. However there remain some unsolved problems. Troxell divided the coins of the League into five periods (Troxell, 1982, 15). Period II is subdivided into 3 series. The first of these dates from the end of the II century to 88 B.C. The second, Series II was issued between 88 and 84 B.C. and Series 3 was dated to between 84 and 77 B.C. (Troxell, 1982, 98). The initial minting by Olympus in the Lycian League began during Period II. These coins carried $\Lambda \mathrm{YKI} \Omega \mathrm{N}$ as the ethnicon of the League (Troxell, 1982, 107; Behrwald, 2000, 107). While the other member cities of the League continued to strike coins, Olympus left to mint its own in Period III (Troxell, 1982, 106, Table 4) indicating the separation or expulsion of Olympus from the League. The city did not strike coins for a long period in Period IV and V, minting its next emission, of autonomy coins during the reign of Emperor Gordianus (Von Aulock, 1977, 71-72, Taf. 11-12, Kat.186-90).

At the end of 1970's a trove containing 133 League coins was discovered, probably from Kemer (Von Aulock, 1977, 34; Troxell, 1982, 29). Of this hoard 91 are from Eastern Lycia. 76 of these are from Olympus and Phaselis, while 15 are from Limyra, Rhodiapolis and Gagai. Olympus had 58 coins that belonged to the League and those coins which carry only the abbreviation of city name $\mathrm{O} \Lambda \mathrm{YM} \Pi \mathrm{H}$ in Series 2 and 3; while the period II, series 1 coins carry the $\Lambda$ v́кıv ( $\Lambda$ YKION/ $\Lambda$ YKI $\Omega N$ ) legend (see: Table) with those coins from Olympus and Phaselis which carry only the abbreviation of the city name without the legend $\Lambda \mathrm{YKI} \Omega \mathrm{N}$ are termed Pseudo-League coins (Troxell, 1982, 69; Behrwald, 2000, 106). This difference marks the separation of both cities from the League and their capture by the pirates. The dating of these Pseudo-League coins agrees with the period when these cities were captured by the pirates.

According to the ancient sources Olympus, Corycus, Attaleia and their territories were dominated through the pirate's poverty (Cic. Leg. Agr. II 50; Eutr. VI. 3). The pirate chief Zenicetes (More information see: Arslan, 2003a, 195-211; Arslan, 2003b, 91-118; Uğurlu, 2007, 81104; Öztürk, 2007, 58; Arslan, \& Tüner-Önen, 2011, 189-206) ruled from his military base on Mount Olympus (Strab. XIV. 5. 7). The Lycian League coins in Period II, Series 1 are dated to the period from the end of the II century to 88 B.C. The Olympus coins in Series 1 are represented by only 3 League examples but the Pseudo-League coins include 33 examples which certainly indicate a link between the domination of the pirates and the issuance of 
Pseudo-League coins. Pseudo-League coins begin to be issued at the end the II century, around 100 B.C. and continued to 77 B.C. with the series 3 examples (the Olympus Series 3 examples are not found in the Kemer hoard). Although these coins imitated the Lycian League examples, they do not carry the League ethnicon. It is thought that Olympus and Phaselis minted these coins on behalf of the pirates against the interests of the League (Troxell, 1982, 84, 90, 93). Olympus probably removed itself or was removed from the League because of the city's being captured by Zenicetes or because of Olympus collaboration with the pirates (Jones, 1998, 104105). The inscription dated to 81 B.C. which was found in the Sanctuary of Hecate at Carian Lagina, recorded the six members of the Lycian League and excluded Olympus (Moretti, 1962, 202; Balland, 1981, 176). Limyra probably replaced Olympus in its membership of the League (Troxell, 1982, 81; Behrwald, 2000, 106; Tietz, 2003, 316, no. 103) and some scholars have suggested from this inscription, that Olympus at the latest left the Lycian League in 81 B.C. (Adak, 2004, 40).

Servilius Vatia campaigned against the pirates in 78/77 B.C. (Ancient sources: Amm. Marc. XIV. 8. 4; Livy. Per. XC. XCIII; Frontin. strat. III. 7.1; Flor. Epit. I. 41; Eutr. VI. 3; Vell. II. 39; Cic. Leg. Agr. I. 5, II, 50; Verr. I. 56; II. 1. 21; 3. 21; 4. 22; 5. 79; Strab. XIV. 3. 7; Oros. hist. V. 23). Olympus, Phaselis, Attaleia and their territories, ruled by the pirates, were declared "ager publicus (public land) by Rome (Cic. Verr. II. 4. 21). In the other statement mentioning Lycia made by Cicero, Lycia is incorporated in the new Provincia Cilicia following the campaign of Vatia (Cic. Verr. II. 95). But this statement excludes Olympus and Phaselis which were allied to the pirates that Lycia joined to Provincia Cilicia is more possible (Magie, 1950, 1165; Troxell, 1982, 90; Behrwald, 2000, 113). The inscription of the "Anatolia Provincia Customs Law" found in Ephesus and dated to 75 B.C. listed the harbors of Anatolian Provincia (Behrwald, 2000, 108, no. 358; Adak, 2002, 131) and it is understood that Phaselis was not a member of the League and was recorded as a new harbor city in the list of duty stations. According to this information; Olympus, Corycus and the other settlements which are not mentioned in the inscription, were more probably included in Pamphylia than in Cilicia. The other important consequence from this inscription is that Phaselis certainly was not a member of the Lycian League in 75 B.C.

Olympus coined as a member of the League in the II century B.C. but it could not be determined when the city became affiliated with the Lycian League. Olympus and Phaselis minted Lycian League type coins in period II, series 1 (Troxell, 1982, 94-98) and these coins have been dated to between 167 and 130 B.C. (Tek, 2002, 63). Only three coins are known from Olympus and six from Phaselis, from period II, series 1, today. This confirms that both cities were not for a long time members of the League. However, it seems a League accession date earlier than the 130's B.C. for Olympus is more probable. Phaselis was a Greek colony, never a Lycia city in its true sense. From the rock-cut tomb of Topal Gavur discovered about 1990 within the Territorium of Olympus indicates we should consider Olympus was closer to Lycia in cultural terms than Phaselis. The geographical conditions of Olympus are similar, in comparison to Phaselis, with the other cities of Lycia. We suggest Olympus entered the League before Phaselis according with the information provided by Strabo who mentioned Olympus had three vote in the League; the only member from Eastern Lycia and also, as mentioned above, because the city was closer in its cultural and geographical characterics to Lycia when compared to Phaselis.

It can be understood that the people of Olympus benefited from their city's cooperation with the pirates, after the pirates captured the city or through their leader a local man who was 
influenced by pirate activities and, although they wanted to remain a member of the League and to continue their cooperation with it, they must have left the League. It seems they minted the Pseudo League coins and continued in their commercial development. Olympus had probably been a member of the Lycian League in the 130's and it left about 100 B.C. From these circumstances, it seems that the non-membership of Olympus in the Lycian League continued for about 30 to 40 years. The ending of the minting of Pseudo-League coins in 77 B.C. can be associated with the campaign of Servilius Vatia against Olympus.

Olympus was again one of the distinguished members of the League during the Roman Imperial Period. In the II century A.D. the Lycian League selected a man from Olympus to declare its decade to Rome (Bean, 1997b, 150). A base found in 2002 in Olympus (Adak, \& Tüner, 2004, 60) which belonged to the tomb of Marcus Aurelius Archepolis and is dated to the end of the II or III century A.D. (Atila, \& Çelgin, 1991, 85-86; Atila, 1992, 114-115) has an inscription which also shows that Olympus was a member of the League in the II century A.D. Both inscriptions and titles (Adak, \& Artvur, 1997, 19; Artvur, 1999, 31; Adak, \& Tüner, 2004, 60) show that Olympus has regained its former distinguished status. On the inscription of the statue base honoring Hoplon of Olympus it is recorded he was a lyciarch as also a grammateus and priest in the Lycian League (Adak, \& Tüner, 2004, 60) and it seems probable that the family of Hoplon continued from about 180 to 300 A.D., similar to the families Iulii and Licinnii from Oenoanda and Claudii-Vii from Patara (Gökalp, 2002, 100). It can also be understood that the Hoplon family were elites of the city, as they had expensive sarcophagi (the sarcophagi imported from Sidamara and Proconnessus) within their vaulted tomb.

There was an extensive network of connections established through marriage between Lycian families during the Roman period. We understand from inscriptions that Lycian citizens not only lived in their own countries but also lived in different cities and regions. For example, Leon, was born in Cyaneai but lived and was buried in Olympus (TAM II. 1012; Zimmermann, 1992a, 75). There were international contacts between the wealthy families of Lycia in the first to III. centuries A.D. For example such contacts are observed between Myra-Tlos and Olympus (TAM II. 944; Zimmermann, 1992a, 236, n 230) and sometimes similar relations extended far beyond the borders of Lycia, extending for example to Rome (TAM II. 495; Zimmermann, 1992a, 236, n. 232).

Table 1. Lycian League, Period II, Olympus Coins

\begin{tabular}{|c|c|c|c|c|c|c|}
\hline SERIES & KT & $\mathrm{OC}$ & $\mathrm{T}$ & TMN & W & Depictions and legends \\
\hline $\begin{array}{l}\text { Series } 1 \\
\text { Series } 1 \text { League Coins } \\
\text { Date: end of the } 2^{\text {nd }} \\
\text { century to } 88 \text { B.C. }\end{array}$ & 2 & 1 & 3 & 1 & $2.76-2.95$ & $\begin{array}{c}\text { PF: Apollon Head, BF. Isis } \\
\text { crown, Kithara and O } \Lambda . \\
\text { (Troxell, 1982, 63, 41. 1a-b, } \\
\text { P1.7) }\end{array}$ \\
\hline $\begin{array}{c}\text { Series } 1 \\
\text { Pseudo-League } \\
\text { Date: end of the } 2^{\text {nd }} \\
\text { century to } 88 \text { B.C. }\end{array}$ & 26 & 7 & 33 & 17 & $\begin{array}{c}.15 / 19,29 ; \\
2.32 / 36,39 ; \\
2.43 / 47 ; 2.51 / 3,6 \\
9 ; 2.61 / 3-5 \\
2.72 / 6-8 ; 2.80 \\
2.90 / 2,94,99 ; \\
3.01 / 7-8 \text { and } 3.26 \\
3.29\end{array}$ & $\begin{array}{c}\text { PF: Apollon head, BF: } \\
\text { helmet, shield and sword } \\
\text { (Troxell, 1982, 42. 1a, 2a-b, } \\
\text { 3a-d, pl.7), O } \Lambda \text { YMПH, } \Delta, \\
\text { I? (Troxell, 1982, 43. 1a-b, } \\
\text { Pl.7); torch, П and M } \\
\text { (Troxell, 1982, 64, 44.1a-b, } \\
\text { Plate 7); trophy, branch } \\
\text { (Troxell, 1982, 45. 1a, 2a-b, } \\
\text { 3a-b, 4a, 5a-b, 6a-b, 7a-b, }\end{array}$ \\
\hline
\end{tabular}




\begin{tabular}{|c|c|c|c|c|c|c|}
\hline & & & & & & $\begin{array}{c}\text { 8a-b, 9a, 10a, 11a, Plate 7, } \\
\text { 45.1-6, Plate 8). }\end{array}$ \\
\hline $\begin{array}{c}\text { Series } 2 \\
\text { Pseudo-League } \\
\text { Date: } 88 \text { to } 84 \text { B.C. }\end{array}$ & 4 & 14 & 18 & 11 & $\begin{array}{c}1.83,2.05,08,12, \\
2.20 / 26 ; \\
2.30 / 31,37,39 \\
2.42 / 47 ; \\
2.50 / 52,58,2.64\end{array}$ & $\begin{array}{c}\text { PF: Apollon head, on one } \\
\text { example: countermarch } \\
\text { quiver, } \\
\text { BF:O } \Lambda \text { YMПН,O } \Lambda \text { YMП, } \\
\text { O } \Lambda \text { YM, torch and shield } \\
\text { and sword (Troxell, 1982, } \\
\text { 72, 51. 1a-d, 2a-c, 3a, 4a, } \\
\text { 5a, 6a, 7a. Plate 10), branch } \\
\text { and flumes (Troxell, 1982, } \\
\text { 52.1a-b, 2a, 3a, 4a, Plate } \\
\text { 10). }\end{array}$ \\
\hline $\begin{array}{c}\text { Series } 3 \\
\text { Pseudo-League } \\
\text { Date: } 84 \text { to } 77 \text { B.C. }\end{array}$ & - & 4 & 4 & 4 & 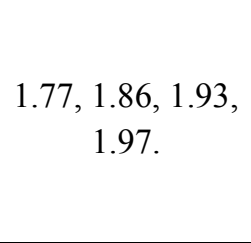 & $\begin{array}{c}\text { PF: Apollon head, BF: } \\
\text { branch and torch?, } \\
\text { O } \text { YMП,O } \Lambda \text { YM (Troxell, } \\
\text { 1982, 74-75, 57.1a, 2a, 3a, } \\
\text { 4a, Plate 11). }\end{array}$ \\
\hline TOTAL & 32 & 26 & 58 & 33 & & \\
\hline
\end{tabular}

The table was prepared from the example provided by Troxell, 1982, Table 1. Abbrevations: KT: Kemer Trove; OC: Other Coins; T: Total; TMN: Total Mould Number; W: Weight; PF: Preface; BF: Back face.

\section{Result}

It is probably Olympus placed came under Zenicetes rule in the period from 104-100 B.C. and exited from the League in these same years. It is conceivable that the Pseudo league coins were minted from c. 100 B.C. If the date of 100 B.C. is accepted as the date when Olympus exited from the league, Zenicetes and probably his kin seem to have ruled Olympus for a period of about twenty years. As a result Olympus won again its statute which had been lost at the end of the Hellenistic age and it seems this continued to the end of the II century and beginning of the III century A.D. 


\section{BIBLIOGRAPHY}

ActaArch. Acta Archaeology.

Adak, M. (2002). “Lykia ve Roma”. Ed. S. Şahin, Lykia İncelemeleri, 1, 129-36, İstanbul: Arkeoloji ve Sanat Yayınları.

Adak, M. (2004). "Lokalisierung von Olympos und Korykos in Ostlykien”. Gephyra, 1, 27-52.

Adak, M., \& Atvur, O. (1997). "Das Grabhaus des Zosimos und der Schiffseigner Eudemos aus Olympos". EA, 28, 11-27.

Adak, M., \& Tüner, N. (2004). "Neu Inschriften aus Olympos und seinen Territorium I”. Gephyra, 1, 53-66.

Adak, M., \& Wilson, M. (2012). "Das Vespasiansmonument von Döşeme und die Gründung der Doppelprovinz Lycia et Pamphylia". Gephyra, 9, 1-40.

Amm. Marc. Ammianus Marcellinus, Rerum gestarum libri. English translation by J. C. Rolfe, I-III, London: 1935-1939. (The Loeb Classical Library).

AnatSt. Anatolien Studies.

ANRW. Aufstieg und Niedergang der römischen Welt.

App. civ. Appianus, Bella Civilia. Appian's Roman History. With an English translation by H. White, IIIIV. London/New York: 1923-1928, (The Loeb Classical Library).

Arslan, M. (2003a). "Piracy on the Southern Coast of Asia Minor and Mithridates Eupator". Olba, VIII, 195-211.

Arslan, M. (2003b). “İ.Ö. 188 Yılından İÖ. 63 Yılına Kadar Lykia, Pamphylia ve Kilikia Trakheia Sahillerindeki Korsanlık Faaliyetleri. Nedenleri ve Sonuçları”. Adalya, VI, 91-118.

Arslan, M., \& Tüner-Önen, N. (2011). “Akdeniz’in Korsan Yuvaları: Kilikia, Pamphylia, Lykia ve Ionia Bölgelerindeki Korykoslar”. Adalya, XIV, 189-206.

Atila, İ. A., \& Çelgin, A.V. (1991). "Likya'da, Olympos'ta Bulunan Bir Mezar Anıtı". MSU FEFD, Sayı 1, 75-105.

Atila, İ. A. (1992). “Olympos Mezar Odası Kurtarma Kazıları”. II. MüzeKK, 105-28.

Atvur, O. (1999). “Olympos Antik Kenti (1991-1992 Çalışmaları)”. Arkeoloji ve Sanat Dergisi, 88, 13-31.

Balland, A. (1981). Fouilles de Xanthos VII, Inscriptons d'epoque impériale du Letoon. Paris.

Bean, G. (1948). "Notes and Inscriptions from Lycia". JHS, 68, 40-58.

Bean, G. 1997a. Eskiçă̆da Lykia Bölgesi. Çev. H. Kökten. İstanbul: Arion Yayınevi.

Bean, 1997b. Eskiçağda Güney Klyılar. Çev. İ. Delemen, \& S. Çokay. İstanbul: Arion Yayınevi.

Bean, G., \& Mitchell, S. (1996). "Lycia. Oxford Classical Dictionary”. Ed. S. Hornblower \& A. Spatworth, 894-5. Oxford: Oxford University Press.

Behrwald, R. (2000). Der Lykische Bund. Untersuchungen zu Geschichte und Verfassung. Bonn.

Borchhardt, J. (1997). “Zur Politik Der Dynasten Trbbênimi und Perikle von Zêmuri”. LYKİA, III, 1-23.

Borchhardt, J. (1999). Limyra, Zemuri Taşları. Çev. G. Yümer. İstanbul: Arkeoloji ve Sanat Yayınları.

Brandt, H. (1992). Gesellschaft und Wirtschaft Pamphyliens und Pisidiens, im Altertum. Münster: Habelt.

Bryce, T. (1986). The Lycians: A Study of Lycian History and Civilisation to the Conquest of Alexander the Great I: The Lycians in Literary and Epigrafic Sources. Copenhag: Museum Tusculanum Press.

Büyükkolanc1, M. (2004). “Termessos Q1 Anıtı ve Iphigenia Kabartmaları”. Festschrift für F. Işık zum 60. Geburstag. 209-18. Ed. T. Korkut, H. Işık \& G. Işın. İstanbul: Ege Yayınları.

Cic. Leg. Agr. Cicero, De lege agraria = The Speeches of Cicero. With an English translation by J. H. Freese, London/New York: 1930, (The Loeb Classical Library).

Cic. Verr. Cicero, In Verrem. The Verrine Orations. With an English translation by L. H. G. Greenwood, I-II. London/New York: 1928-1935, (The Loeb Classical Library).

Childs, W. A. P. (1981). "Lycian Relations with Persians and Greeks in the fifth and fourth Centuries ReExamined". AnatSt, 31, 55-80.

Dio. Cass. Cassius Dio, Rhomaïka = Roman History. With an English translation by E. Carry, I-IX. London: 1914-1927, (The Loeb Classical Library). 
EA. Epigraphica Anatolica.

Eutr. Eutropius, Brevarium ab urbe condita = The Breviarum ab Urbe Condita of Eutropius. Translated with an Introducion and Commentary by H. W. Bird. Liverpool, 1993.

Flor. epit. Annius Florus, Epitoma de Tito Livio = Epitome of Roman History. With an English translation by E. S. Foster, London/New York 1929, (The Loeb Classical Library).

Frontin. strat. Sextus Iulius Frontinus, Strategematon = The Strategems and the Aqueducts of Rome. With an English translation by C. E. Ennett, London/New York 1925, (The Loeb Classical Library).

Gephyra. Zeitschrift für Geschichte und Kultur der Antike auf dem Gebiet der Heutigen Türkei. Doğu Akdeniz Bölgesi Eskiçağ Tarihi ve Kültürleri Araştırma Dergisi.

Gökalp, N. (2002). “Oinoanda'dan Bir Soy: Licinnii”. Ed. S. Şahin, Lykia Íncelemeleri, 1, 91-102. İstanbul: Arkeoloji ve Sanat Yayınları.

Günther, V. (1988). "Milesische Bürgerrechts-UN Proxeni everlei- hungen der Hellenistischen Zeit". Chiron, 18, 383-419.

Gygax M. D. (2001). Untersuchungen zu den lykischen Gemeinwesen in klassischer und hellenistischer

Zeit. Bonn. Antiquitas, Reihe 1, Abhandlungen zur alten Geschichte, Bd. 4. Press.

Habicht, C. (1998). Pausanias' Guide to Ancient Greece. California, University of California.

Hall, A., \& Milner, N. (1994). "Education and athletics. Documents illustrating the Festivals of Oenoanda". Studies in the History and Topography of Lycia and Pisidia. Memoriam A.S. Hall. 7-47. Ed. D. French. Ankara: The British Institute of Archaeology at Ankara Pub.

Head, B.V. (1967²). Historia Numorum: a Manual of Greek Numismatics. $2^{\text {nd }}$ ed., Oxford: Oxford University Press.

Houwink ten Cate, P. H. J. (1961). The Luwian Population Groups of Lycia and Cilicia Aspera during the Hellenistic Period. Leiden: Brill Academic Pub.

Hdt. Herodotus. With an English transation by A. D. Godley, vol. I-V. London, New York: 1975, (The Loeb Classical Library).

IstMitt. Istanbuler Mitteilungen.

Işın, G. (1994). “The Easternmost Rock Tomb in Lycia: Topal Gavur at Asartaş”. Lykia, 1, 68-75.

İplikçioğlu, B. (2008). "Die Provinz Lycia unter Galba und die Gründung der Doppelprovinz Lycia et Pamphylia unter Vespasian”. Anzeiger der philosophisch-historischen Klasse der Österreichischen Akademie der Wissenschaften, 143/2, 5-23.

Jameson, S. (1980). "The Lycian League Some Problems of its Administration”. ANRW II, 7/2, 832-55.

JHS. Journal of Hellenistic Studies.

Jones, A. H. M. (1998). The Cities of the Eastern Roman Provinces. Oxford: Sandpiper Books. Original edition 1937, Oxford: Oxford University Press.

Keen, A.G. (1998). Dynastic Lycia. A Political History of the Lycians and Their Relations with Foreign Powers C. 545-362. Boston: Brill Academic Publishers.

Larsen, J.A.O. (1945). "Representation and Democracy in Hellenistic Federalizm”. Cph, 40, 65-97.

Kokkinia, C. (2000). Die Opramoas-Inschrift von Rhodiapolis. Euergetismus und soziale Elite in Lykien. Antiquitas, 3, Bonn.

Kokkinia, C. (2012). Opramoas' citizenship: The Lycian politeuomenos-formula, in: A. Heller and V. Pont (eds.) Patrie d'origine et patries électives: les citoyonnetés multiples dans le monde grec d'époque romaine (Actes du collogue international de Tours, 6-7 novembre

2009), Bordwaux, 327-371.

Larsen, J.A.O. (1956). “The Araxa inscription and the Lycian Confederacy”. Cph, 51, 151-169.

Larsen, J.A.O. (1968). Greek Federal States: Their Institutions and History. Oxford: Clarendon Press.

Livy. Per. Titus Livius, Periochae. London: 1947, (The Loeb Classial Library).

Magie, D. (1950). Roman Rule in Asia Minor to the End of the Third Century after Christ, vol. 2. Princeton: Princeton University Press.

Meyer, E. (1925). Die Grenzen der Hellenistischen Staaten in Kleinasien. Zürich, and Leipzig: Orell 
Fiissli Press.

Milner, N. (1991). "Victors in the Meleagria and the Balbouran Élite". AnatSt, 41, 23-62.

Moretti, L. (1950). "Una nova inscrizione de Araxa”. RFIC, 28, 326-350.

Moretti, L. (1962). Ricerche sulle leghe greche, (Peloponnesiaca-Boetica-Licia), Problemi e ricerche di storia antica: 2. Roma: L'Erma" di Bretschneider Press.

Morkholm, O. \& Zahle, J., (1972). "The Coinage of Kuprilli. A Numismatic and Archaeological Study". ActaArch, 47, 47-90.

MüzeKK. Müze Kurtarma Kazıları.

Ormerod, H. A. (1997). Piracy in the Ancient World. London: Buccaneer Books Original edition, 1924.

Oros. hist. Orosius, Historiae adversus paganos = Seven Books of History Against the Pagans. Translated with Introduction and Notes by I. W. Raymond, New York: 1936.

Öztürk, H.S. (2007). M.Ö. II.- M.S. IV. yüzylllarda Likya-Pamfilya Bölgesinde Kırsal Alan Güvenliği. Yayınlanmamış Doktora Tezi. Marmara Üniversitesi, İstanbul.

Reitzenstein, D. (2011). Die lykischen Bundespriester. Repräsentation der kaisezeitlichen Elite Lykiens. Klio Beiheftige NF, Band 17. Berlin, Berlin Academia.

Patterson, L. E. (2010). Kinship Myth in Ancient Greece. Austin: Univrsity of Texas Press.

Paus. Pausanias, Pausanian Description of Greece. With an English translation by W. H. Jones, vols. I-V. London, New York: 1918-1935, (The Loeb Classical Library).

Price, S. R. F. (2004). Ritüel ve İktidar, Küçük Asya'da Roma Imparatorluk Kültü. Çev. T. Esin. İstanbul: İmge Kitabevi.

Strab. Strabon, The Geography of Strabo. With an English translation by H. L. Jones, vols. I-VIII. London. New York: 1917-1932, (The Loeb Classical Library).

Souza, P. De. (1999). Piracy in the Roman World. Cambridge: Cambridge University Press.

Suet. Clad. Suetonius, De Vitae Caesarum, Claudius = The Lives of the Caesars. With an English translation by J. C. Rolfe. London, New York: 1924, (The Loeb Classical Library).

Şahin, S. (1994). "Ein Vorbericht über den Stadiasmus Provinciae Lyciae in Patara”. Lykia, 1, 130-137.

Şahin, S., \& Adak, M. (2007). Stadiasmus Patarensis. Itinera Romana Provincae Lycae. İstanbul, Ege Yayınları.

Takmer, B. (2007). Lex Portorii Provinciae Lyciae. Ein Vorbericht über die Zollinschrift aus Andriake aus neronischer Zeit. Gephyra, 165-188.

TAM II. Kalinka, E Tituli Asie Minoris II: Tituli Lyciae linguis Graeca et Latina conscripti, I, Pars Lyciae occidentalis cum Xantho oppido 2: Regio quae ad Xanthum flumen pertinet praeter Xanthum oppidum, 3: Regiones montanae a valle Xanthi fluminis ad oram orientalem Wien.

Tek, A. T. 2002. Arykanda Kazılarında Bulunan Antik Sikkeler Üzerinde Yeni Incelemeler: 1971-2000 Sezonları. Yayınlanmamış Doktora Tezi. Ankara Üniversitesi, Ankara.

Tietz, W. (2003). Der Gulf von Fethiye, Politische, Ethnische und Kulturelle Strukturen einer Grenzregion vom Beginn der Nachweisbaren Besiedlung bis in die Römische Kaiserzeit. Bonn: Antiquitas 1.

Treuber, O. (1887). Geschichte der Lykier. Stutgart, Tübingen: Druck Von H. Laupp.

Troxell, H. A. (1982). The Coinage of the Lycian League. New York: The American Numismatik Society, Numismatic Notes and Monographs no. 162.

Uğurlu, E. (2007). “Olympos ve Zeniketes'in Kalesinin Lokalizasyonu”. Adalya, X, 81-104.

Val. Max. Valerius Maximus = Valerius Maximus and the Rhetoric of the New Nobility. With an English translation by W. M. Bloomer, London: 992.

Vell. Velleius Paterculus, Historia Romana = Velleius Paterculus, Compendium of Roman History. With an English translation by F. E. Shipley. London/New York 1924, (The Loeb Classical Library).

Von Aulock, H. (1977). Die Münzprägung des Gordian III und der Tranquillina in Lykien. IstMitt. Beiheft 11.

Wade, M., \& Mcgregor, G. (1968). The Athenian Tribute List II. Princeton: ASCSA.

Wörlle, M. (1997). "Die Inschriften am Grab des Apollonis Asartaş von Yazır in Ostlykien”. LYKIA, III, 
24-38.

Wörlle, M. (1998). Stadt und Fest kaiserzeitlichen Kleinasien. Studien zu einer Agonistichen Stiftung aus Oinoanda. Munich.

Zimmermann, M. (1992a). Untersuchungen zur Historischen Landeskunde Zentrallykiens. Bonn: Abhandlungne zur Alten Geschichte 42. Antiquitas Reihe I.

Zimmermann, M. (1992b). "Die Lykischen Häfen und die handelswege im Östlischen Mittelmeer: Bemerkungen zu Pmich 1-10". ZPE, 92, 201-17.

Zimmermann, M. (1993). "Zwischen Polis und Koinon zum hypophylaks im lykischen Bund". Epigraphica Anatolica, 21, 107-120.

ZPE. Zeitschrift für Papyrologie und Epigraphik. 